\title{
LACUNARITY PROPERTIES OF NANOPHOTONIC MATERIALS BASED ON POLY(METHYL METHACRYLATE) FOR CONTACT LENSES
}

\author{
RAZPOREDITEV PRAZNIN NANOFOTONIČNEGA MATERIALA \\ NA OSNOVI POLI(METIL METAKRILATA) ZA KONTAKTNE LEČE
}

\author{
Marija Tomić1, Božica Bojović², Dragomir Stamenković3, Ivana Mileusnić1, \\ Djuro Koruga ${ }^{1,4}$ \\ ${ }^{1}$ University of Belgrade, Faculty of Mechanical Engineering, Department of Biomedical Engineering, NanoLab, \\ Kraljice Marije 16, 11120 Belgrade, Serbia \\ ${ }^{2}$ University of Belgrade, Faculty of Mechanical Engineering, Department of Production Engineering, \\ Kraljice Marije 16, 11120 Belgrade, Serbia \\ ${ }^{3}$ Optix LLC, Oracka 13, 11070 Belgrade, Serbia \\ ${ }^{4}$ University for Peace established by the United Nations, Department of Biomedical Engineering and Nanomedicine, \\ ECPD, Terazije 41, 11000 Belgrade, Serbia \\ marija.m.tomic@gmail.com
}

Prejem rokopisa - received: 2016-01-17; sprejem za objavo - accepted for publication: 2016-02-05

doi:10.17222/mit.2016.014

\begin{abstract}
The aim was to develop new materials that would, after appropriate machining processes, improve the surface roughness and wettability of contact lenses. The samples used in this investigation were standard rigid gas-permeable (RGP) SOLEKO contact lenses, made of poly-MMA-co-siloxy silane methacrylate material (known under the commercial name SP40 ${ }^{\mathrm{TM}}$ ), and its modifications by adding three nanomaterials: fullerene $\mathrm{C}_{60}$ (designated as SP40-A), fullerol $\mathrm{C}_{60}(\mathrm{OH})_{24}$ (designated as SP40-B) and methformin hydroxylate fullerene $\mathrm{C}_{60}(\mathrm{OH})_{12}\left(\mathrm{OC}_{4} \mathrm{~N}_{5} \mathrm{H}_{10}\right)_{12}$ (designated as SP40-C). Both atomic force microscopy (AFM) and magnetic force microscopy (MFM) were used to measure the topography and gradient of the magnetic field of the nanophotonic materials and the reference samples. According to the magnetic properties of all the materials yielded by MFM it can be concluded that adding fullerene and its derivatives certainly reduces the spectrum of the phase shifts angle by almost $50 \%$, which increases the paramagnetic characteristics of the nanophotonic material. The positive result of nanophotonic materials characterization is the fact that the roughness parameter values for all of these materials, are lower than those for the basic material. A surface lacunarity analysis, based on in-house procedures for determining the lacunarity value of contact lens surfaces, confirms the influence of surface topology on the tear film volume distribution and, consequently, the contact lens' surface lubrication. The presence of carbon nanomaterials, according to the surface roughness parameters, are improved for rigid gas-permeable (RGP) contact lenses made from nanophotonic polymer materials compared to those produced from the basic material.

Keywords: fullerenes, polymer materials, surface roughness, atomic force microscopy, magnetic force microscopy
\end{abstract}

Namen je bil razviti nov material, ki bi po ustrezni strojni obdelavi zmanjšal hrapavost površine in omočljivost kontaktnih leč. Vzorci, uporabljeni v tej raziskavi so bile standardne toge, za plin prepustne (RGP) SOLEKO kontaktne leče, narejene iz poli-MMA-ko-siloksi silan metakrilatnega materiala (s komercialnim imenom poznanega SP40 ${ }^{\mathrm{TM}}$ ) in njihove modifikacije dodatkom treh nanomaterialov: fulerena $\mathrm{C}_{60}$ (označenega kot SP40-A), fulerola $\mathrm{C}_{60}(\mathrm{OH})_{24}$ (označenega z SP40-B) in metformin hidroksilat fulerena $\mathrm{C}_{60}(\mathrm{OH})_{12}\left(\mathrm{OC}_{4} \mathrm{~N}_{5} \mathrm{H}_{10}\right)_{12}$ (označenega z SP40-C). Uporabljeni so bili: mikroskopija na atomsko silo (AFM), mikroskopija na magnetno silo (MFM) za merjenje topografije in gradient magnetnega polja nanofotonskih materialov in referenčnih vzorcev. Skladno z magnetnimi lastnostmi vseh materialov, dobljenih z MFM, je mogoče zaključiti, da dodajanje fulerenov in njegovih izpeljank, močno zmanjša spekter kotov faznega premika za skoraj $50 \%$, kar poveča paramagnetne značilnosti nanofotonskih materialov. Pozitivni rezultati karakterizacije nanofotonskih materialov so, da so vrednosti parametra hrapavosti pri vseh teh materialih nižje kot pri osnovnem materialu. Analiza površinske razporeditve praznin, na osnovi doma razvite tehnologije za določanje vrednosti razporeditve praznin na površini kontaktnih leč, je pokazala vpliv topologije površine na razporeditev plasti solz in posledično na mazanje površine kontaktnih leč. Prisotnost ogljikovih nanomaterialov je glede na parametre hrapavosti površine, izboljšala plinsko propustnost togih, za plin prepustnih (RGP) kontaktnih leč, izdelanih iz nanofotonskega polimernega materiala, v primerjavi s tistimi izdelanimi iz osnovnega materiala.

Ključne besede: fulereni, polimerni materiali, hrapavost površine, mikroskopija na atomsko silo, mikroskopija na magnetno silo

\section{INTRODUCTION}

The tear film is a liquid layer that covers the cornea and conjunctiva keeping the surface of the cornea smooth and making it optically clear. While blinking, the tear film lubricates the friction area between lids and ocular surface ${ }^{1}$. The precorneal tear film thickness, which is related to dry eye and corneal integrity, is reported in range from $45 \mu \mathrm{m}^{2}$ to $3 \mu \mathrm{m} .^{3-5}$ When a rigid gas-permeable (RGP) contact lens is placed on the eye, the tear film is divided into two layers, the pre-lens and post-lens tear film. The importance of tear exchange behind an RGP contact lens remains an ongoing debate. ${ }^{6}$ Once a contact lens is inserted, the value of the precorneal tear film thickness doubles, resulting in a 2-5 $\mu \mathrm{m}$ thickness for pre and post lens tear films. Some authors ${ }^{7}$ determined the post lens tear film below $3 \mu \mathrm{m}$. 


\section{MATERIALI IN TEHNOLOGIJE/MATERIALS AND TECHNOLOGY (1967-2017) - 50 LET/50 YEARS}

\section{TOMIĆ et al.: LACUNARITY PROPERTIES OF NANOPHOTONIC MATERIALS BASED ON ...}

J. L. Creech et al. ${ }^{8}$ have concluded that tear film thickness is an important parameter that varies among individuals. The presence of any contact lens on the front surface of the eye influences and disturbs tear film stability. These changes in the tear film are caused by contact lens design, surface, material and applied solution for conditioning. The quality of a machined surface is determined by its roughness, which is described by the surface topography (i.e., the height differences between specific points of the surface), as well as by their exact position in regard to some reference area. The surface roughness of a contact lens has various implications, such as comfort, post lens tear film disruption and tear component deposition.

The aim is to test the response of a material's surface roughness quality to retain the tear film on the nano-level using a gliding-box method for lacunarity analysis. Surface lacunarity analysis is an innovative approach based on the work of B. Mandelbrot ${ }^{9}$, R. Voss $^{10}$ and R. E. Plotnick $^{11}$. B. Mandelbrot introduced the term lacunarity from the Latin word 'lacuna', which is related to the English 'lake'. 9 Lacunarity describes the degree of 'gappiness' of the fractal and is a complement to fractal dimension, because fractal dimension measures how much space is filled, whereas lacunarity measures how the fractal fills space. Intuitively, more and larger gaps give a higher lacunarity. ${ }^{12}$ Although originally developed for further classification of fractals as a counterpart to the fractal dimension ${ }^{10}$, lacunarity application is more general, as presented and illustrated in R. E. Plotnick. ${ }^{11}$ Lacunarity analysis is broadly applicable to many data sets used in natural sciences ${ }^{13,14}$, as a very useful multiscaled method for describing patterns of spatial dispersion. The fractal analysis can also be applied to biological samples such as microglia (the brain's immuno-inflammatory cell). This analysis may contribute significantly to the next steps forward in engineered tissues and 3D models in neuroscience. ${ }^{15}$

Taking these issues into account, the idea was to develop new contact lens materials that would, after an appropriate lathing and polishing process, improve the roughness parameters. There is a need for more precise measurements of the surface roughness as well as for detecting the physical properties of surfaces. To measure the topography and gradient of the magnetic field of nanophotonic materials, as well as of reference samples, both atomic force microscopy (AFM) and magnetic force microscopy (MFM) were used.

\section{MATERIALS AND METHODS}

\subsection{Nanophotonic materials}

New nanophotonic materials based on fullerene $\mathrm{C}_{60}$ and its derivatives ${ }^{16-18}$ have been developed for the production of RGP contact lenses. Fullerenes and their derivatives show strong electron affinity, acting like 'radical sponges', and they easily enter addition reac- tions with nucleophiles. One of the main disadvantages of fullerenes is their low solubility in water. In order to make them soluble, they have to be functionalized with polar groups such as $-\mathrm{OH}$ and $-\mathrm{COOH}$. Of all the water-soluble fullerenes the most important are those with $-\mathrm{OH}$ groups attached, called fullerols or fullerenols, (nano- $\left.\mathrm{C}_{60}(\mathrm{OH})_{24}\right)$. These fullerene derivatives have shown promise as drug carriers to bypass the brain and ocular barriers and have been approved for use in nano-cosmetics, although fullerols have been found to be cytotoxic to HaCaT keratinocytes, a transformed epidermal human cell line and human dermal fibroblasts. ${ }^{19}$

The properties of $\mathrm{C}_{60}$ can also be modified by its incorporation into polymers, making it a material that can be easily handled and produced. Combining both systems has led to a wide variety of new materials with appealing features based on the possibility of tuning their properties by modifying the chemical nature of the components or the chemical linkage between them. ${ }^{20}$ The easiest method of incorporation of $\mathrm{C}_{60}$ into a polymer is radical copolymerization, which can produce materials of widely varied fullerene content, but the degree of substitution of the fullerene is hard to control, and the structures are heterogeneous and hard to determine. ${ }^{21}$

The aforementioned nanomaterials were incorporated into the standard RGP SOLEKO ${ }^{\mathrm{TM}}$ material (Pontecorvo, Italy) known by the commercial name $\mathrm{SP} 40^{\mathrm{TM}}$. This material belongs to the group of polymers known as poly-MMA-co-siloxy silane methacrylate, whose optical characteristics are given in Table $\mathbf{1}$. The polymerization was made separately on three samples by adding $1 \mathrm{~g}$ of each nanomaterial to the basic Soleko SP40 ${ }^{\mathrm{TM}}$. Therefore, three new materials were produced, designated SP40-A (fullerene $\mathrm{C}_{60}$ ), SP40-B (fullerol $\mathrm{C}_{60}(\mathrm{OH})_{24}$ ) and SP40-C (methformin hydroxylate fullerene $\left.\mathrm{C}_{60}(\mathrm{OH})_{12}\left(\mathrm{OC}_{4} \mathrm{~N}_{5} \mathrm{H}_{10}\right)_{12}\right)$. The percentage of nanomaterials in the solution was $0.33 \%$ and although they were not completely dissolved in methylmethacrylate, the polymerization was homogeneous in all the samples. The fourth polymerization was conducted without nanomaterials so the regular Soleko SP40 ${ }^{\mathrm{TM}}$ RGP material was used as a reference sample. The preparation of the samples was conducted at the Soleko, Italy laboratories. Each material was cut into a cylindrical sample of $12.8 \mathrm{~mm}$ diameter and $5.2 \mathrm{~mm}$ height. The samples were cut in a row from a rod produced by polymerization, providing optimal repeating. The contact lenses were manufactured by using a computer numerical control

Table 1: Optical characteristics of material SP40

Tabela 1: Optične značilnosti materiala SP40

\begin{tabular}{|l|c|c|}
\hline \multicolumn{1}{|c|}{ Optical characteristics } & Value & Test \\
\hline $\begin{array}{l}\text { Transmission in the visible } \\
\text { part of the spectrum }\end{array}$ & $>90 \%$ & ISO 8599 \\
\hline $\begin{array}{l}\text { Transmission in the UV part } \\
\text { of the spectrum }\end{array}$ & $\begin{array}{c}<60 \% \\
(290-330 \mathrm{~nm})\end{array}$ & ISO 8599 \\
\hline Refractive index & $1.472 \pm 0.003$ & ISO 9914 \\
\hline
\end{tabular}


(CNC) lathe (Politech 1800 Aspheric-Toric) and polishing as a finishing process.

\subsection{Atomic force microscopy and magnetic force mi- croscopy}

Both surfaces of the contact lens can be characterized by AFM, which allows the characterization of surface topography and surface roughness. AFM images are obtained by scanning a sharp probe across a surface while monitoring and compiling the tip-sample interactions to provide an image..$^{22}$ The atomic force microscope used in this study was a JSPM-5200 (JEOL, Japan). MFM mode allows us to obtain the topography of the sample, but on the other hand provides information about the magnetic properties (magnetic gradient) of the material. In order to obtain both topography and magnetic gradient images, MFM operates in a so-called 'lift mode'. ${ }^{23,24}$ The lift mode or a two-pass technique is used to separate the effects of the magnetic and mechanical tip-sample forces.

The probe (cantilever) used in this study was produced by MikroMasch (Estonia) under the trade name NCS18/Co-Cr. The length of the cantilever is $230 \mu \mathrm{m}$, and a typical spring constant is $3.5 \mathrm{~N} / \mathrm{m}$. The tip curvature radius is $10 \mathrm{~nm}$, but that is the radius of the uncoated tip. It is necessary to add a coating of ferromagnetic material to provide the magnetic field. This coating consists of a Co layer about $60 \mathrm{~nm}$ thick on the tip and backside of the probe. The Co coating is protected from oxidation by a $20-\mathrm{nm}$ Cr layer. This leads to a total tip radius of $90 \mathrm{~nm}$. All measurements were made at room temperature (around $23{ }^{\circ} \mathrm{C}$ ) under the atomic force microscope's glass bell to minimize the effects of temperature fluctuations. In phase imaging, the phase lag of the cantilever's oscillation relative to the drive signal is simultaneously monitored with topography data. Because the phase imaging highlights the edges and is not affected by large-scale height differences, it provides a clearer observation of the fine features, which can be obscured by rough topography.

The imaging area for RGP contact lenses was $2 \times 2 \mu \mathrm{m}$, $256 \times 256$ pixels. Images obtained during the AFM/MFM scanning were analyzed using JEOL SPM Processing Software and WinSxM. ${ }^{25}$ The parameters used for materials comparison are the height difference between the lowest and the highest point on the topography image $\left(S_{z}\right)$ and the areal arithmetic mean deviation $\left(S_{a}\right)$. Parameter $S_{a}$ is calculated using Equation (1): ${ }^{26}$

$$
S_{a}=\frac{1}{S_{0}} \int_{0}^{x_{\max }} \int_{0}^{y_{\max }}\left|f(x, y)-Z_{0}\right| \mathrm{d} x \mathrm{~d} y
$$

where $f(x, y)$ is the function of surface asperities on the image in pixels denoted by $(x, y), S_{0}$ is the image area and $Z_{0}$ is an average topography height. On the magnetic field gradient (phase images), relevant parameters are the maximum phase shift angle $(\alpha)$, minimum $\alpha$ and the entire spectrum of phase shift angles.

\subsection{Lacunarity analysis}

Based on the gliding box method proposed by $\mathrm{R}$. Voss $^{10}$ and R. E. Plotnick ${ }^{11}$, the procedures for determining the lacunarity values of the contact lens surfaces were developed using Matlab software. All the necessary image processing was also performed in Matlab. First, the surface topography image was considered as a matrix filled by surface height in each pixel. Such a matrix represents an intensity image type with a grayscale map. Second, the maximum height is divided into 100 levels. Surface topography images are sliced on these levels by planes starting from the top and all the way down. For each section the pixels that belong to a surface are colored white and considered as binary 1 . The rest of the surface image belongs to valleys, so they represent an empty space. Those pixels are colored black and are considered as binary 0 .

This method considers the gliding box as a window systematically moving through the binary image. The gliding box could be moved either in a fixed scan or in an overlapping window sliding manner. Regardless of the sliding manner, the box mass value $m$ is determined for each of the gliding boxes as a number of black pixels occupied by the gliding box. The gliding box size $r$ is a variable and can take values of $2^{n}$ pixel length. According to R. E. Plotnick ${ }^{11}$, lacunarity $L(r)$ is defined by Equation (2):

$$
L(r)=\frac{M_{2}(r)}{M_{1}^{2}(r)}
$$

where $M_{1}(r)$ and $M_{2}(r)$ are the first and second moments of the distribution of black pixels in the gliding box. The moments are defined by Equations (3) and (4):

$$
\begin{gathered}
M_{1}(r)=\sum_{m=1}^{r^{2}} m \cdot P(m, r) \\
M_{2}(r)=\sum_{m=1}^{r^{2}} m^{2} \cdot P(m, r)
\end{gathered}
$$

The probability $P(m, r)$ that the gliding box of size $r$ contains $m$ black pixels is defined by Equation (5):

$$
P(m, r)=\frac{n(m, r)}{N(r)}
$$

where $n(m, r)$ is the number of box size $r$ with mass $m$, and $N(r)$ is the total number of boxes of size $r$.

If the calculated lacunarity $L(r)$ is plotted in a double logarithmic diagram then fractals will have straight-line plots, in other words, they have a similar appearance across scales. Otherwise, multi-fractals will have a different plot with few distinct areas, which means that they do not have a similar appearance across scales. The lacunarity plot for fractals can be fitted by a single line, but the multi-scaled object has to be fitted with several straight lines. Research done by R. E. Plotnick ${ }^{11}$ offers double logarithmic plots for visual lacunarity distinction concerning either fractals or non-fractals. It provides 
M. TOMIĆ et al.: LACUNARITY PROPERTIES OF NANOPHOTONIC MATERIALS BASED ON ...
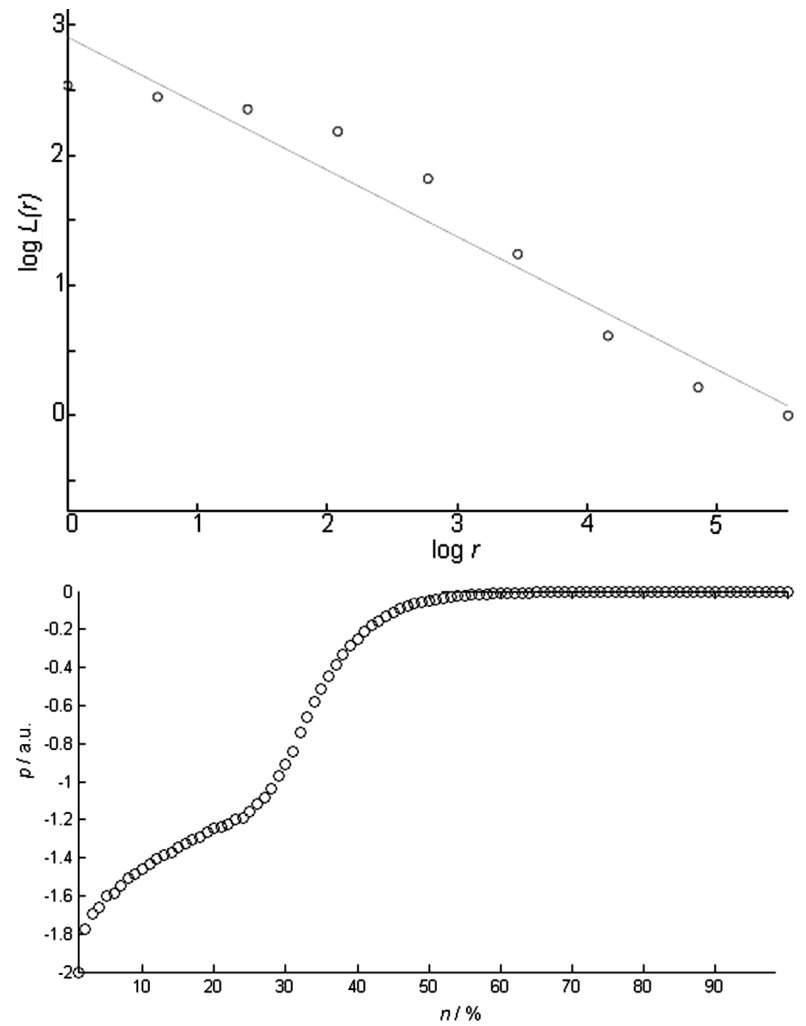

Figure 1: a) Plot of logarithms of $L(r)$ against $r$ for arbitrary cutting level of the engineering surface and b) slope value $p$ vs. cutting level $n$ Slika 1: a) Diagram logaritmov $L(r) \mathrm{v}$ odvisnosti od $r$ za arbitrarno stopnjo rezanja inženirske površine in b) vrednosti naklona $p$ v odvisnosti od nivoja $n$

visual information about the pixel entropy of the image representing the surface. The double logarithmic plot shown in Figure $\mathbf{1}$ can serve as a basis for a comparison of different object plots.

The line slope as a numerical value $p$ is suggested ${ }^{22}$ as a parameter that can be used for the AFM image lacunarity comparison. In the case of surface topography, particularly for binary images that are made by sectioning on levels of interest, the lacunarity double log plot (Figure 1 (left)) can be used for a surface section comparison. However, the number $p$ as a slope value for every section can serve as a parameter for the surface section characterization. Additionally, if parameter $p$ is plotted for every section made by slicing the surface
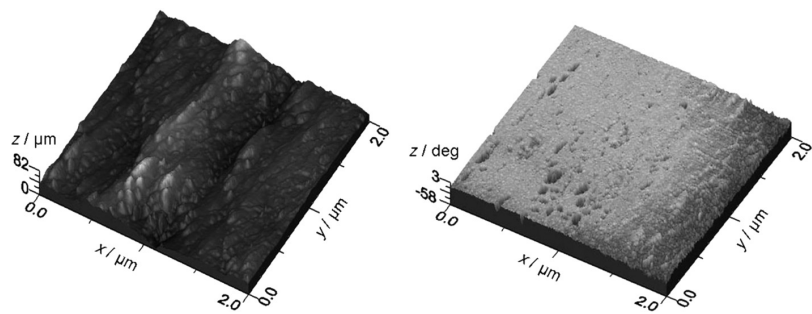

Figure 2: Average 3D topography image (left) and 3D magnetic force gradient (right) of basic material SP40

Slika 2: Posnetek povprečne 3D-topografije (levo) in 3D-gradient magnetne sile (desno) osnovnega materiala SP40
AFM image, then the diagram shown in Figure 1 (right) can be considered as the AFM image lacunarity signature. The plots shown in Figure $\mathbf{1}$ have been made according to Equation (6):

$$
\lg L(r)=c+p \cdot \lg r
$$

The diagram, which consists of three sloped curves, can be connected to randomly distributed surface asperities generated by the machining process, as demonstrated in the work by B. Bojovic et al. ${ }^{27}$

Lacunarity analysis offers two types of $p$-diagrams, which were presented in our previously reported work. The first type represents $p$-diagrams with four line slopes and we labeled them as contorted $p$-diagrams. In contrast to them is a second type consisting of slanted $p$-diagrams with three line slopes. Images associated with a specific type of diagrams demonstrate similar surface topology. The contorted $p$-diagram is related to topology with distinctive high hills and the slanted $p$-diagram is designated by regularly distributed asperities.

\section{RESULTS AND DISCUSSION}

The average results for the topography and gradient of the magnetic field investigations into the 12 investigated samples are presented in Figures 2 and 3. Topography images are necessary to provide information about the surface roughness and to see whether there are any potential bumps on the surface that could cause damage to the cornea or make wearing the contact lens uncomfortable.
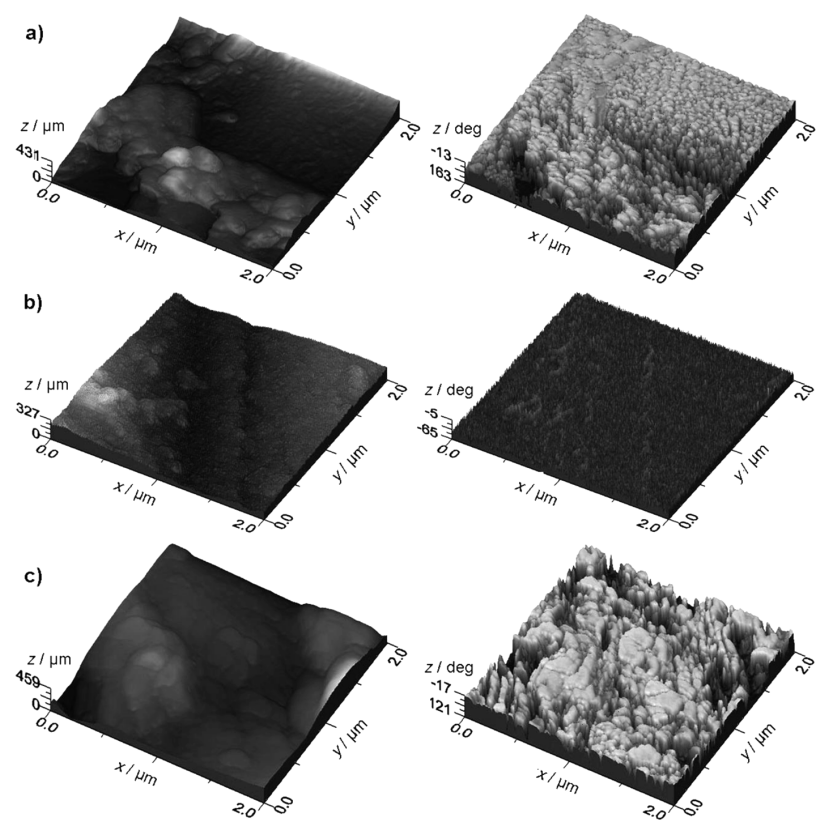

Figure 3: Average 3D topography image (left) and 3D magnetic force gradient (right) of nanophotonic materials a) SP40-A, b) SP40-B and c) SP40-C

Slika 3: Posnetek povprečne 3D-topografije (levo) in 3D-gradient magnetne sile (desno) nano fotonskih materialov, a) SP40-A, b) $\mathrm{SP} 40-\mathrm{B}$ in c) SP40-C 
As presented in D. Stamenkovic ${ }^{28}$ all the materials possess topography that is smooth enough to fit the human eye. The maximum height difference of all materials can be seen on the topography of the basic material, and nanophotonic materials have smoother topographies. SP40 has the largest $R_{z}$ value of $331.8 \mathrm{~nm}$, which is much lower than the human tear film, as expected from commercially available materials. However, nanophotonic materials are proven to have much smaller height differences, where the second largest $R_{z}$ of material SP40-C is $157.2 \mathrm{~nm}$, which is more than half the $R_{z}$ of $\mathrm{SP} 40$. The basic material has the largest surface roughness of $23.4 \mathrm{~nm}$. The second largest is material SP40-A, and then material SP40-C with a surface roughness of $9.19 \mathrm{~nm}$. It is interesting that material SP40-C, although it has the second largest $R_{z}$, has a smoother surface than material SP40-A. ${ }^{28}$

The images of the gradient value of the magnetic field show that all materials have paramagnetic properties. The largest phase-shift angle difference is for the basic material, suggesting there are particles inside as impurities or that there are conglomerates of basic material with a higher density that have the largest differences in magnetic properties. Also, it can be seen that the basic material possesses the highest paramagnetic characteristics, with a minimum phase shift angle of $-121.6^{\circ}$. However, a maximum phase shift of $-10.8^{\circ}$ shows a large variability in the paramagnetic properties. All nanophotonic materials show much smaller differences in the phase shift angles, which means that they have more consistent magnetic properties and density distributions (more homogenous). Also, it can be seen that nanophotonic materials tend to shift magnetic properties even more to paramagnetism, which is more strongly expressed in material SP40-A and material SP40-C.

\subsection{Lacunarity analysis}

For the contact lens lacunarity analysis, the topographic image of each material was recorded and imported to Matlab (Version R2013a, license number 853706) for further calculation. Four surfaces of four RGP contact lens materials were gathered. In order to make lacunarity perceptible for the integral contact lens surface, the parameter $p$ is determined for every section made by slicing the AFM image.

The slanted form of $p$-diagrams can be seen in the case of the RGP contact lenses made of SP40 base materials (Figure 4). Topography images related to RGP materials group of diagrams demonstrate a similar surface topology (Figure 4). Consequently, the $p$-diagrams look alike and have similar line slopes through the levels. Only the $p$-diagram for the SP40-C material exhibits a line slope change in the range $20-32 \%$ of maximum height. All $p$-diagrams reach asymptotic zero value after a certain level where materials become predominant, which is related to empty space in deep valleys. The surfaces of all four RGP contact lens materials include large regions of material in the bottom half $(20 \%)$ of the maximum height, which makes the object very dense and the $p$-value obtains a constant value.

The frontal surface of a contact lens is in direct contact with the inner part of the upper eyelid. With each blink of the eye the upper eyelid covers the frontal surface with a tear film, thus filling in the gaps and smoothing the surface roughness. The surface of a contact lens with too many irregularities (high roughness) is undesirable because the tear film would not be sufficient to cover them, particularly at the end of the day when post lens tear film gets significantly thinner. According to the lacunarity analysis and observed line slope change in the range $20-32 \%$ of maximum height, the nanophotonic lens surface made of SP40-C material exhibits a less desirable topography. However, by combining the surface maximal height with an unwanted elevations distribution, it could be concluded that they are significantly lower compared to the post lens tear film thickness.

From an optics (refraction) point of view, a surface with minor irregularities is not a disadvantage. Furthermore, 'over polished' surfaces have decreased wettability, which results in rapid 'breakage' of the tear film on the frontal surface of the lens. Besides aforementioned, 'over polished' surfaces have lower adhesion force which keeps the RGP lens in eye. Considering these specific requirements for functional behavior it could be concluded that nanophotonic lenses have an even more suitable topography compared to the conventional one.

Surface topography with deep valleys causes the contact lens to attract more proteins, lipids and other components of a tear film. These deposits have a negative effect on the optical characteristics of a contact lens, as well as on comfort. The results presented in the $p$-diagrams that is related to empty space in deep valleys indicate that all four RGP contact lens materials are appropriate for diminishing deposits.

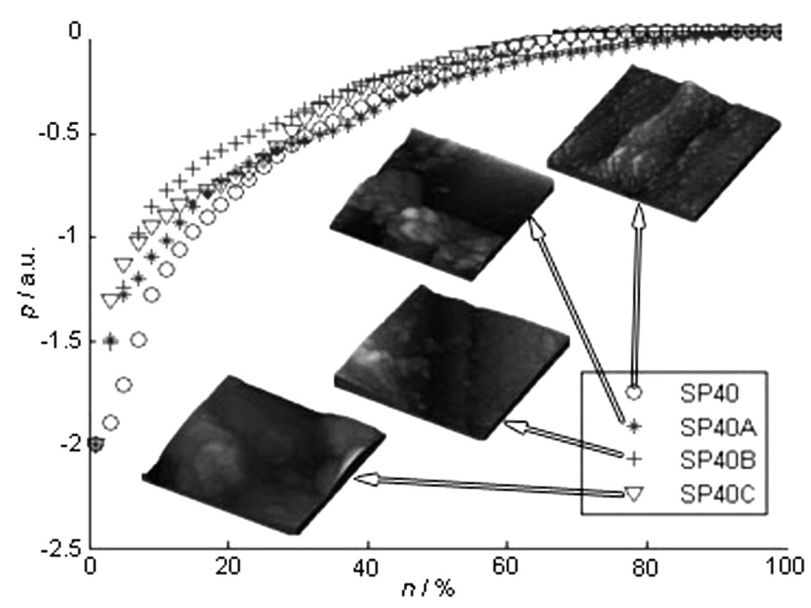

Figure 4: Plot of parameter $p$ vs. cutting level $n$ for RGP contact lens surface

Slika 4: Diagram parametra $p$ v odvisnosti od nivoja rezanja $n$ na površini RGP kontaktnih leč 


\title{
MATERIALI IN TEHNOLOGIJE/MATERIALS AND TECHNOLOGY (1967-2017) - 50 LET/50 YEARS
}

\author{
M. TOMIĆ et al.: LACUNARITY PROPERTIES OF NANOPHOTONIC MATERIALS BASED ON ...
}

\section{CONCLUSION}

The results presented here suggest the future commercialization of nanophotonic materials is affirmative. As suggested in D. Stamenkovic ${ }^{30}$ the AFM method has shown that the quality of polished surfaces for all three nanophotonic materials completely satisfies the standards for the production of contact lenses since they have a smoother surface than SP40. The positive result is the fact that the roughness parameter values for all nanophotonic materials are lower than those for the basic material. ${ }^{30}$

According to the magnetic properties of all the materials yielded by MFM it can be concluded that the basic material had very large phase shift angle differences, which are reduced by adding fullerene and its derivatives. The incorporation of these carbon nanomaterials caused the spectrum of phase shift angles to be reduced by almost $50 \%$. Also, although even the basic material has demonstrated paramagnetic properties it can be seen that adding carbon nanomaterials increases the paramagnetic characteristics of the material.

Topography images show that bumps significantly influence the surface lacunarity, because they embrace a great deal of lubricant volume. Therefore, the origins of the contorted $p$-diagram are bump-like entities. Considering the functional behavior of the contact lens surface, irregularities like bumps are unwanted, and thus this kind of contact surface cannot be considered acceptable. The surface lacunarity influences the tear film volume distribution and, consequently, the contact lens surface lubrication.

The surface lacunarity behavior can be related to the surface topology. The results of the surface lacunarity analysis confirm the sample surface state as belonging to an appropriate (slanted $p$-diagram) roughness concerning the tear film stability. Regarding the tribological behavior that depends on lacuna distribution on the surface, the RGP contact lenses made of three nanophotonic materials and machined in the usual manner are enhanced compared to commercially available ones. Those lacunas preserve a critical amount of tear film in the case of dry eye and therefore improve the lubrication process during RGP contact lens wearing.

\section{Acknowledgements}

This research was funded by the Ministry of Education, Science and Technological Development of the Republic of Serbia, through Project III45009. We would like to thank Soleko, Italy, for turning our initial ideas about new materials into a reality by producing them with us in their laboratories.

\section{REFERENCES}

${ }^{1}$ A. J. Bron, J. M. Tiffany, S. M. Gouveia, N. Yokoj, L. W. Voon, Functional aspects of the tear film lipid layer, Exp. Eye Res. 78 (2004) 3, 347, doi:10.1016/j.exer.2003.09.019

2 J. I. Prydal, P. Arral, H. Woon, F.W. Campbell, Study of Precorneal Tear Film Thickness and Structure by Interferometry and Confocal Microscopy, Invest. Ophtalmol. Vis. Sci. 33 (1992) 6, 1996

${ }^{3}$ P. Smith, B. Fink, N. Fogt, K. Nichols, R. Hill, G. Wilson, he Thickness of the Human Precorneal Tear Film: Evidence from Reflection Spectra, Invest. Ophtalmol. Vis. Sci. 41 (2000) 11, 3348

${ }^{4}$ J. Wang, D. Fonn, T. L. Simpson, L. Jones, Precorneal and Pre- and Postlens Tear Film Thickness Measured Indirectly with Optical Coherence Tomography, Invest. Ophtalmol. Vis. Sci. 44 (2003) 6, 2524, doi:10.1167/iovs.02-0731

${ }^{5}$ K. Azartash, J. Kwan, J. R. Paugh, A. L. Nguyen, J. V. Jester, E. Gratton, Pre-corneal tear film thickness in humans measured with a novel technique, Mol. Vis. 17 (2011), 756

${ }^{6}$ A. Muntz, L. N. Subbaraman, L. Sorbara, L. Jones, Tear exchange and contact lenses: A review, J. Optom. 8 (2015) 1, 2, doi:10.1016/ j.optom.2014.12.001

${ }^{7}$ J. J. Nichols, P. E. King-Smith, Thickness of the pre- and postcontact lens tear film measured in vivo by interferometry, Invest. Ophtalmol. Vis. Sci. 44 (2003) 1, 68, doi:10.1167/iovs.02-0377

${ }^{8}$ J. L. Creech, L. T. Do, I. Fatt, C. J. Radke, In vivo tear-film thickness determination and implications for tear-film stability, Curr. Eye Res. 17 (1998) 11, 1058-1066, doi:10.1076/ceyr.17.11.1058.5233

${ }^{9}$ B. Mandelbrot, The Fractal Geometry of Nature, W. H. Freeman and Co., New York, 1982

${ }^{10} \mathrm{R}$. Voss, Random fractals: characterization and measurement, Scaling Phenomena in Disordered Systems, Springer, 1986, 51-61

${ }^{11}$ R. E. Plotnick, R. H. Gardner, W. W. Hargrove, K. Prestegaard, M. Perlmutter, Lacunarity analysis: A general technique for the analysis of spatial patterns, Phys. Rev. E 53 (1996) 5, 5461, doi:10.1103/ PhysRevE.53.5461

${ }^{12}$ C. Allain, M. Cloitre, Characterizing the lacunarity of random and deterministic fractal sets, Phys. Rev. A 44 (1991) 6, 3552, doi:10.1103/PhysRevA.44.3552

${ }^{13}$ P. Borys, M. Krasowska, Z. J. Grzywna, M. B. A. Djamgoz, M. E. Mycielska, Lacunarity as a novel measure of cancer cells behavior, Biosystems 94 (2008) 3, 276, doi:10.1016/j.biosystems.2008.05.036

${ }^{14} \mathrm{~S}$. Hoechstetter, U. Walz, N. Thinh, Adapting lacunarity techniques for gradient-based analyses of landscape surfaces, Ecol. Complex. 8 (2011) 3, 229, doi:10.1016/j.ecocom.2011.01.001

${ }^{15}$ A. Karperien, H. Jelinek, Fractal, multifractal, and lacunarity analysis of microglia in tissue engineering, Front. Bioeng. Biotechnol. 3 (2015) 51, 1, doi:10.3389/fbioe.2015.00051

${ }^{16}$ H. W. Kroto, J. R. Heath, S. C. O’Brien, R. F. Curl, R. E. Smalley, $\mathrm{C}_{60}$ : Buckminsterfullerene, Nature 318 (1985), 162, doi:10.1038/ $318162 \mathrm{a} 0$

${ }^{17}$ Dj. Koruga, S. Hameroff, J. Withers, R. Loutfy, M. Sundareshan, Fullerene C60: History, Physics, Nanobiology, Nanotechnology, Elsevier, Amsterdam, 1993

${ }^{18}$ M. S. Dresselhaus, G. Dresselhaus, P. C. Eklund, Science of Fullerenes and Carbon Nanotubes, Academic Press, Inc., New York, 1996

${ }^{19}$ P. Taroni, C. D'Andrea, G. Valentini, R. Cubeddu, D.N. Hu, J. E. Roberts, Fullerol in human lens and retinal pigment epithelial cells: time domain fluorescence spectroscopy and imaging, Photochem. Photobiol. Sci. 10 (2011), 904, doi:10.1039/c0pp00312c

${ }^{20} \mathrm{~F}$. Giacalone, N. Martín, Fullerene polymers: synthesis and properties, Chem. Rev., 106 (2006) 12, 5136, doi:10.1021/cr068389h

${ }^{21}$ W. T. Ford, T. Nishioka, S. C. McCleskey, T. H. Mourey, Structure and Radical Mechanism of Formation of Copolymers of $\mathrm{C}_{60}$ with Styrene and with Methyl Methacrylate, Macro- molecules 33 (2000) 7, 2413, doi:10.1021/ma991597+

${ }^{22}$ C. R. Blanchard, Atomic force microscopy, Chem. Educator 1 (1996) 5, 1, doi:10.1007/s00897960059a 


\section{MATERIALI IN TEHNOLOGIJE/MATERIALS AND TECHNOLOGY (1967-2017) - 50 LET/50 YEARS}

M. TOMIĆ et al.: LACUNARITY PROPERTIES OF NANOPHOTONIC MATERIALS BASED ON ...

${ }^{23}$ U. Hartmann, Magnetic force microscopy: Some remarks from micromagnetic point of view, J. Appl. Phys. 64 (1988) 3, 1561, doi: $10.1063 / 1.341836$

${ }^{24}$ U. Hartmann, Magnetic force microscopy, Ann. Rev. Mater. Sci. 29 (1999) 53, doi:10.1146/annurev.matsci.29.1.53

${ }^{25}$ JEOL SPM 5200, Instruction manual, 2005

${ }^{26}$ ISO 25178: Geometric Product Specifications (GPS) - Surface texture: areal-Part 2 (2013)
${ }^{27}$ B. Bojovic, M. Petrovic, Z. Miljkovic, B. Babic, L. Matija: Lubrication prediction in digital manufacturing, Proc. of the $6^{\text {th }}$ Inter. Working Conference TQM, Belgrade, Serbia, 2011, 475

${ }^{28} \mathrm{D}$. Stamenkovic, Investigation and development of rigid gas permeable nanophotonic contact lenses based on poly (methyl methacrylate) and fullerene, $\mathrm{PhD}$ Thesis in Serbian, Faculty of Mechanical Engineering, University of Belgrade, 2012 